\title{
Regenerative Engineering of Cartilage Using Adipose-Derived Stem Cells
}

\author{
Rafid Kasir $^{1,2,3}$ • Varadraj N. Vernekar ${ }^{1,2,3,4}$ - Cato T. Laurencin ${ }^{1,2,3,4,5,6,7,8}$
}

Received: 7 October 2015 / Accepted: 19 November 2015 / Published online: 30 November 2015

(C) The Regenerative Engineering Society 2015

\begin{abstract}
Injury to the articular cartilage occurs commonly in the general population and undergoes minimal spontaneous healing. Traditional methods of cartilage repair provide no long-term cure and are significant causes of morbidity. For this reason, stem cell therapies have recently been investigated for their ability to regenerate cartilage, and the results have been promising. Since the discovery that adipose tissue is a major source of mesenchymal stem cells in 2001, scientists have been studying the use of adipose-derived stem cells (ASCs) for the treatment of various disorders including lesions of the articular cartilage. ASCs hold several advantages over autologous chondrocytes for cartilage repair, including but not limited to their anti-inflammatory effects, their multi-lineage differentiation potential, and their ability to form new cartilage in a defect. Whereas several investigations have been made in in vitro and animal models, there have been surprisingly little clinical studies on the intra-articular use of adipose-derived stem cells, despite their first isolation about a decade and a half ago. The few studies that have been conducted are
\end{abstract}

Rafid Kasir and Varadraj N. Vernekar share co-first authorship.

Cato T. Laurencin

laurencin@uchc.edu

1 Institute for Regenerative Engineering, University of Connecticut Health Center, Farmington, CT 06030, USA

2 Raymond and Beverly Sackler Center for Biomedical, Biological, Physical and Engineering Sciences, University of Connecticut Health Center, Farmington, CT 06030, USA

3 School of Medicine, University of Connecticut Health Center, Farmington, CT 06030, USA encouraging. With approval for various stem cell therapies on the horizon, this review seeks to update the clinician and the researcher on the current state-of-the-art use of adipose-derived stem cells for the treatment of cartilage disorders and the regenerative engineering of cartilaginous tissue.

\section{Lay Summary}

Among the most disabling conditions, joint cartilage disorders lack regenerative treatments. Current best alternatives involve major surgery that replaces the entire joint or smaller graft procedures, both with potential short-comings. Stem cells hold tremendous potential for tissue regeneration. Easily expendable fat tissue is an abundant source of stem cells. Recently, there have been a few promising reports in humans on the regenerative effects of fat tissue-derived stem cells in cartilage disorders. This review updates the reader on the current state of art in cell isolation, implantation, and clinical outcomes using fat-derived stem cell-based regenerative therapy for cartilage disorders.
4 Department of Orthopaedic Surgery, University of Connecticut Health Center, Farmington, CT 06030, USA

5 Department of Reconstructive Sciences, University of Connecticut Health Center, Farmington, CT 06030, USA

6 Department of Chemical and Biomolecular Engineering, University of Connecticut, Storrs, CT 06269, USA

7 Department of Biomedical Engineering, University of Connecticut, Storrs, CT 06269, USA

8 Department of Materials Science and Engineering, University of Connecticut, Storrs, CT 06269, USA 
Keywords Adipose-derived stem cells $\cdot$ ADSC $\cdot$ ASC . Mesenchymal stem cells $\cdot$ Cartilage $\cdot$ Disorders ·

Osteoarthritis $\cdot$ Repair $\cdot$ Regeneration $\cdot$ Regenerative . Medicine $\cdot$ Engineering

\section{Background}

Cartilage disorders are a major cause of disability worldwide [1]. Additionally, it remains a considerable challenge that cartilage has a limited potential for self-regeneration and spontaneous repair [2]. The poor regenerative capability of chondral tissue is attributed to the avascular environment that chondrocytes reside in [3], as this prevents the access and survival of stem cells to the injured area for repair and regeneration [4].

Current techniques to treat cartilage disorders range from graft procedures to cell based therapy. Osteochondral autograft transfer is a technique that involves the transfer of small osteochondral cylinders from non-weight-bearing areas to the defect. While cost effective and time efficient, this procedure is limited by donor site availability and morbidity [5]. On the other hand, allograft transfer eliminates the donor site morbidity but adds the risk of disease transmission [6]. Furthermore, neither of these procedures is indicated to treat the most common type of cartilage disorder: osteoarthritis (OA) [7].

Early attempts to promote cartilage self-repair were focused on penetrating the subchondral bone with abrasion arthroplasty [8], microfracture [9], or subchondral drilling [10]. It was hypothesized that damaging the bone directly beneath the lesion would lead to the recruitment of pluripotential cells from the proximal bone marrow and open a pathway for these cells to migrate and engage in repair [11]. These procedures were introduced approximately 30 years ago as an alternative to total knee replacement and currently underlie the arthroscopic debridement process [12]. However, a randomized clinical trial in 2002 to assess the efficacy of such arthroscopic treatment of the osteoarthritic knee showed no improvement in pain or function between the treatment and placebo groups at any point in time during follow-up [13]. There is currently no evidence-based indication for the use of arthroscopic therapy in OA [14], and at best, the procedures are considered to be palliative, not curative [15].

The emergence of newer cell based approaches has introduced a therapeutic modality for articular cartilage repair [16]. These methods can be divided into stem cell and non-stem cell based therapy. The use of non-stem cells involves filling chondral defects with autologous chondrocytes from a less loaded donor site. The donor cells are expanded in vitro and a second surgery is required to implant them. Although autologous chondrocyte implantation (ACI) has well-established clinical outcomes and has been refined since 1987 [17, 18], the procedure still requires two surgeries, is associated with substantial donor site morbidity [19], and is limited to small focal defects not typical of OA [18]. In contrast, adult mesenchymal stem cell therapy has been a proposed treatment for chondral lesions including those seen in osteoarthritis; it has seen numerous clinical applications and circumvents several of the previous limitations of ACI [20-25].

\section{Mesenchymal Stem Cells}

The multipotent and specifically chondrogenic properties of mesenchymal stem cells (MSCs) have been known for decades [26]. These adult stem cells have provided an attractive alternative to the ethically debated use of embryonic stem cells in regenerative medicine. The MSCs are characterized by their potential to differentiate into adipocytes, chondrocytes, and osteoblasts, their capacity to adhere to plastic under standard culture conditions, and their phenotype (CD73+, CD90+, CD105+, CD14- or CD11b-, CD19- or CD79a-, CD45- and HLA-DR-) [27]. Once MSCs are isolated, growth factors such as transforming growth factor-beta and bone morphogenetic protein can be used to induce chondrogenesis [28].

While numerous studies have reported benefits in treating cartilage injuries with MSCs, it remains unclear if the regenerative effects of MSCs are due to secretory cytokine action on the injured and surrounding tissue or if the cells survive implantation and restore native tissue directly with their own cellular machinery and differentiation into chondrocytes [29]. The emphasis of many recent investigations has been on the secretory actions of the multipotent cells rather than their functional differentiation $[30,31]$. Regardless of the mechanism of action, multiple studies have demonstrated that there is both a regenerative and symptomatic improvement of chondral lesions with MSCs.

Mesenchymal stem cells are present in numerous tissues and have been traditionally harvested from bone marrow [32]. However, autologous bone marrow procurement is not without its limitations; it is a painful and invasive procedure that is associated with significant morbidity [33]. Moreover, deriving MSCs from bone marrow yields low cell numbers upon processing (approximately 1 MSCs per $10^{5}$ aspirated bone marrow cells) $[34,35]$. Generously assuming, a concentration of $3 \times 10^{7}$ nucleated cells per $\mathrm{mL}$ of bone marrow aspirate [36] would result in approximately only $600 \mathrm{MSCs}$ per $\mathrm{mL}$ of marrow. This necessitates in vitro expansion in order to obtain clinically effective cell counts. In addition to the cost and time associated with such a process, it introduces the risk of contamination. A source of MSCs that is abundant and easily attainable while yielding sufficient cell numbers (to avoid in vitro expansion) would be an ideal candidate for clinical medicine. 


\section{Adipose-Derived Stem Cells}

Mesenchymal stem cells are believed to be intimately linked with blood vessels, often residing in the perivascular locations [37]. Because adipose tissue is rich in capillary beds, this diffuse tissue harbors one of the largest available depots of MSCs. The isolation of a new group of mesenchymal stem cells from adipose tissue, now termed adipose-derived stem cells (ASC) [38], was first described in 2001 by Zuk et al. [39]. These pluripotent cells have subsequently been shown to have an extensive proliferative capacity and the ability to differentiate into the endoderm, mesoderm, and ectoderm lineages [40]. The chondrogenic properties of ASCs cannot be disputed, and some studies suggest that they may hold greater potential for long-term cartilage function than differentiated chondrocytes. Specifically, while chondrocytes steadily lose the ability to produce type II collagen in vitro after each passed generation, ASCs have been shown to hold and maintain greater chondrogenic potential for over 15 expansions [41, 42].

There has been extensive research into the specifying characteristics of ASCs. There is a general consensus among investigators that the ASC is positive for markers of MSCs as well as CD34+ and CD31-/CD45- [43]. Notably, the phenotypical examinations of ASCs have confirmed a lack of HLAclass II antigen on the cell surface [44]. Host antibodies against donor HLA-class II cell surface receptors are associated with transplant failure, and studies have shown that there is no recorded evidence of graft versus host disease or rejection in using ASCs allogenically or even xenogenically [44]. Furthermore, ASCs suppress local immune reactions [45], which may contribute to their regenerative abilities. In fact, in transplant medicine, ASCs have been used clinically with living donor renal transplants to minimize the use of immunosuppressive agents and provide better outcomes [46]. Therefore, autoimmune cartilage disorders such as rheumatoid arthritis may especially benefit with ASC therapy, and early results in in vitro models are encouraging [47]. The use of ASCs is not limited to immune modulated disorders, and recently, the use of these cells has been shown to effectively treat chondral lesions in osteoarthritis [48].

\section{ASC Isolation}

The abundance and easy accessibility of adipose tissue make it an ideal candidate for the supply of MSCs. It is arguably the most expendable tissue in the human body and can be harvested safely under local anesthesia. The last report investigating the safety profile of liposuction was performed in 2002 and showed zero deaths between 1994 and 2000 following 66,570 liposuction procedures, with a serious adverse event rate of only $0.068 \%$ [49]. The number of liposuctions performed continues to rise annually, with approximately 350,000 liposuction surgeries completed in 2014 [50]. Yields after a typical liposuction procedure range from $100 \mathrm{~mL}$ to $5 \mathrm{~L}$ of lipoaspirate, and this tissue is almost always discarded [51]. Zuk et al. developed a widely used method for isolating ASCs in 2001 [39]. Adipose tissue is first obtained via liposuction, followed by collagenase digestion of the ECM, and centrifugation to obtain the remaining pellet known as the stromal vascular fraction (SVF). The SVF contains endothelial cells, smooth muscle cells, erythrocytes, leukocytes, adipocytes, and a small number of adipose-derived stem cells. Lastly, adipose-derived stem cells are obtained as the plasticadherent population after overnight culturing of the SVF.

The ASC yield after processing lipoaspirate is significantly higher than that of MSCs after processing bone marrow aspirate. As mentioned previously, approximately only $0.001 \%$ of all bone marrow stromal cells aspirated have been shown to hold multipotent properties [34]. From a practical standpoint, this yields approximately $50-675 \mathrm{MSCs}$ per $\mathrm{mL}$ of bone marrow aspirate [35]. In contrast, anywhere from $1 \times 10^{5-6} \mathrm{ASCs}$ have been routinely obtained from $1 \mathrm{~mL}$ of lipoaspirate [39]. Such significantly higher yields allow for plausible immediate intraoperative clinical use and can potentially eliminate the currently necessary ex vivo expansion of bone marrowderived MSCs. Some of the advantages of adipose-derived stem cells over bone marrow derived stem cells as a therapeutic source are summarized in Fig. 1.

Multiple methods of ASC isolation have been proposed since the 2001 description [52]. Newer methods claim quicker and cheaper isolation [40], and some attempt to bypass enzyme digestion all together [53]. Because a key step in adipose-derived stem cell retrieval is the isolation of the SVF (the pellet of mixed cell types after centrifugation of collagenase-treated lipoaspirate), many commercial devices

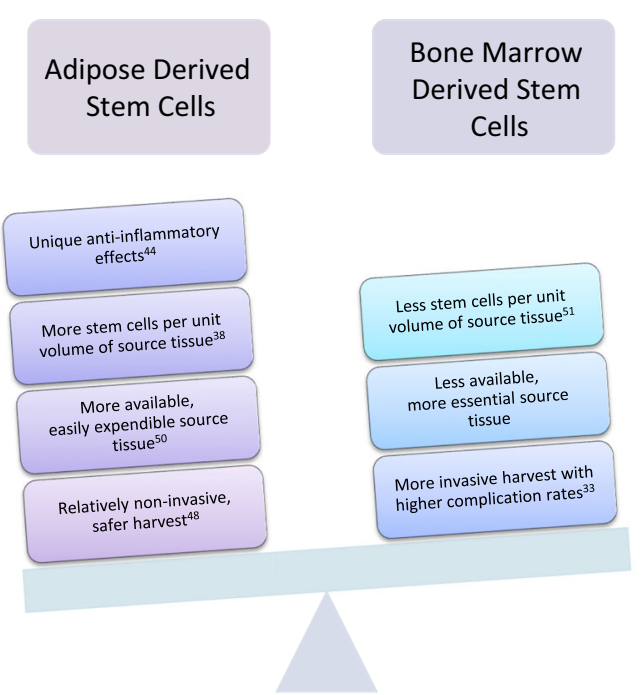

Fig. 1 Comparison of bone marrow derived stem cells, adipose-derived stem cells, and their isolation 
have surfaced over the last decade targeting SVF isolation. In 2013, Aronowitz et al. performed a head to head comparison of four such commercial cell separation devices and determined that of the four, the Cytori Celution 800/CRS System had both the highest cell yield and lowest residual enzyme levels after a mean processing time of $1.5 \mathrm{~h}$ [54].

Nevertheless, it is worth noting that none of the current devices separate ASCs from the other cells in the stromal vascular fraction. Likewise, many of the technologies marketed as adipose-derived stem cell isolation technologies are in reality just "fat purifying" devices. The pure isolation of ASCs requires a way of cell sorting from the SVF. Current practice is to accomplish this by overnight culture of the SVF on tissue-culture plastic and selecting the most adherent cell type with a combination of washing and culture expansion. This process may not be feasible during one procedure in the operating room. Therefore, the use of the stromal vascular fraction itself, which contains a small, but significant proportion of ASCs, may be the best available therapeutic option within a single surgical setting at this point in time. This has resulted in contention in some recent papers that purported the use of ASCs/MSCs in the treatment of chondral lesions, when a processed lipoaspirate was actually injected into the joints [55-57]. The clinical effects of using pure ASCs may in fact be very different than the use of the SVF. Although results by Kim et al. show that purified SVF is still therapeutically beneficial, likely because of the presence of ASCs, it is important to note that no group has isolated and evaluated the effects of the other components in the SVF. Furthermore, it remains a possibility that the use of the SVF in regenerating cartilage is superior to the use of purified ASCs. Nevertheless, the development of a same-day technique that isolates ASCs from the stromal vascular fraction for immediate implementation within the operating room is of significant interest.

\section{ASC Implantation and Regnerative Engineering}

The delivery of ASCs to treat chondral lesions ranges from simple intra-articular injections to using advanced biological scaffolds as vehicular platforms for the cells. The intraarticular injection has been most commonly performed and studied with encouraging results in animals [58, 59]. However, Vilar et al. have shown that while simple ASC injections are efficacious in treating cartilage defects, the significant load bearing improvements of cartilage in dogs with hip OA after ASC injections gradually decreased to baseline after 3 months [60]. This transient effect suggests that injected ASCs may not integrate well with host tissue.

Meanwhile, different types of biomaterials such as sponges, meshes, fibers, and hydrogels that are derived from biodegradable synthetic and natural polymers are being investigated as advanced biological scaffolds to replace or restore the function of damaged cartilage [61]. The tissue-engineered biomaterial scaffolds can facilitate the attachment, proliferation, and differentiation of embedded cells, and studies using ASCs and scaffolds have been conducted in vitro and in animals [62, 63]. Investigations showed that adding ASCs to various scaffolds led to the filling of chondral defects with reparative hyaline cartilage that consisted of significant amounts of type II collagen. In contrast, scaffolds with no ASCs displayed lesions filled with fibrosis on follow-up. These results show a clear benefit to adding ASCs to a scaffold [62, 63].

Zhang et al. have shown that a water-soluble polypeptide scaffold could support ASC growth, attachment, and chondrogenic differentiation in vitro, and upon addition of the scaffold/cell combination to full thickness cartilage defects in rabbits, they showed near normal cartilage regeneration by 12 weeks [64]. Recently, Kim et al. have shown that using ASCs loaded in fibrin glue provided no functional or pain advantage over the injection of ASCs alone [48]. However, they did note significant improvements in International Cartilage Repair Scoring (ICRS) when using a fibrin glue scaffold. Although the contribution of the fibrin glue in the cartilage healing process has not been systematically evaluated, these results suggest a long term benefit.

Many scaffolds have been used to repair tissue. While it is exciting to combine two promising technologies (i.e., ASCs and scaffolds) in treating cartilage disorders, it is important to be aware that various scaffolds could influence the chondrogenic differentiation of ASCs differently, essentially creating a third variable (i.e., the scaffold/stem cell interaction). Thus, for example, scaffolds that may have been previously abandoned due to poor results may be more successful when used in combination with ASCs. The complexity of such investigations is further compounded by the dizzying array of material choices for scaffold delivery. With this in mind, studies must be conducted in a systematic manner with appropriate control groups to determine the ideal method of introducing ASCs into a lesion.

In this regard, nanotechnology, through the creation of biomaterials with unique and defined properties that mimic the cartilaginous extracellular matrix, present temporal and spatial cues for stem cell differentiation into chondrocytes, enable the tracking of the stem cells, and monitor the progress of tissue development, can be a strong enabling technology. Beyond nanotechnology and stem cell science, our evolving understanding of developmental biology can further inform and enable the engineering of cartilaginous tissue, through what we have defined as regenerative engineering [65].

\section{Human Trials of ASCs for Chondral Lesions}

Current data involving the treatment of cartilaginous lesions in humans with ASCs is limited by size and study type [23-25, 
$48,55,66-72]$. To the best of our knowledge, an exhaustive list of clinical studies using adipose-derived stem cells for cartilage repair is presented in Table 1 . All of these studies have been conducted in South Korea. This has been enabled by the Korean Food and Drug Administration, which in June 2009 opened the use of minimally processed ASCs for autologous cell transplantation [73].

The first clinical report was published in 2011 by Pak who reported on the successful treatment of OA with ASCs [70]. Both elderly women with long standing knee pain due to osteoarthritis had symptomatic improvement and functional improvement after an injection of adipose-derived stem cells along with hyaluronic acid, platelet rich plasma (PRP), calcium chloride, and a nanogram dose of dexamethasone. Furthermore, magnetic resonance imaging (MRI) scans 3 months later showed a significant increase in the thickness and the height of meniscus cartilage. Likewise, in 2014, Pak reported that an MRI performed 3 months after an ASC injection showed almost complete disappearance of a torn meniscus in a 32-year-old female.

In 2012, Koh and Choi sought to evaluate the safety of ASC injections in osteoarthritic knees [23]. They performed

Table 1 Clinical studies using Adipose-Derived Stem Cells in the Treatment of Cartilage Disorders

\begin{tabular}{|c|c|c|c|c|}
\hline Study & Patients & Lesion & Intervention & Results \\
\hline $\begin{array}{l}\text { Pak et al. (July 2011) } \\
\quad[70]\end{array}$ & 2 & Hip OA & SVF, PRP, HA, and dexamethasone & $\begin{array}{l}90 \% \text { pain improvement and significant } \\
\text { increase in meniscal cartilage on } \\
\text { 3-month follow-up MRI }\end{array}$ \\
\hline $\begin{array}{l}\text { Koh et al. (December } \\
\text { 2012) [23] }\end{array}$ & 25 & Knee OA & SVF and PRP & $\begin{array}{l}\text { Degree of improvement in Lycholm and } \\
\text { Tegner scores were superior in the stem } \\
\text { cell group }\end{array}$ \\
\hline \multirow[t]{2}{*}{$\begin{array}{l}\text { Kim et al. (March 2013) } \\
\text { [55] }\end{array}$} & A: 35 & Focal, talus & A: arthroscopic microfracture & $\begin{array}{l}\text { Group B had more significant Tegner and } \\
\text { Pain score improvement }\end{array}$ \\
\hline & B: 30 & & $\begin{array}{l}\text { B: arthroscopic microfracture and } \\
\text { SVF injection }\end{array}$ & \\
\hline $\begin{array}{l}\text { Koh et al. (April 2013) } \\
\text { [25] }\end{array}$ & 18 & Knee OA & SVF and PRP & $\begin{array}{l}\text { Western Ontario and McMaster } \\
\text { Universities Osteoarthritis Index, } \\
\text { Lysholm Scores, VAS, and Whole } \\
\text { Organ MRI score significantly improved }\end{array}$ \\
\hline $\begin{array}{l}\text { Pak et al. (May 2013) } \\
\text { [71] }\end{array}$ & 3 & $\begin{array}{l}\text { Chondromalacia patella, } \\
\text { OA }\end{array}$ & SVF and PRP & $\begin{array}{l}\text { 80-90\% improvement in pain and } \\
\text { restoration of damaged tissue on } \\
\text { 3-month follow-up MRI }\end{array}$ \\
\hline $\begin{array}{l}\text { Koh et al. (December } \\
\text { 2013) [24] }\end{array}$ & 30 & Knee OA & SVF after arthroscopic lavage & $\begin{array}{l}87.5 \% \text { of patients }(14 / 16) \text { receiving } 2 \text {-year } \\
\text { second look arthroscopy improved or } \\
\text { maintained cartilage status, and none } \\
\text { underwent arthroplasty in the } 2 \text { years }\end{array}$ \\
\hline $\begin{array}{l}\text { Pak et al. (December } \\
\text { 2013) [66] }\end{array}$ & 91 & $\mathrm{OA}$ & $\mathrm{SVF}, \mathrm{PRP}, \mathrm{HA}$, and $\mathrm{CaCl}_{2}$ injection & $\begin{array}{l}\text { Pain scores decreased from } 10 \text { to a mean of } \\
4.43 \pm 0.41,3 \text { months after injection }\end{array}$ \\
\hline $\begin{array}{l}\text { Pak et al. (January } \\
\text { 2014) [67] }\end{array}$ & 1 & Meniscal tear & SVF, PRP, $\mathrm{HA}$, and $\mathrm{CaCl}_{2}$ injection & $\begin{array}{l}\text { MRI showed almost complete } \\
\text { disappearance of the torn meniscus } \\
3 \text { months later }\end{array}$ \\
\hline \multirow[t]{2}{*}{$\begin{array}{l}\text { Jo et al. (April 2014) } \\
\text { [72] }\end{array}$} & 9 & Knee OA & $\begin{array}{l}\text { Phase I: patients in each dose group } \\
\text { received } 1.0 \times 10^{7}, 5.0 \times 10^{7} \text {, and } \\
1.0 \times 10^{8} \text { pure ASCs in } 3 \mathrm{~mL} \text { of } \\
\text { saline, respectively }\end{array}$ & $\begin{array}{l}1 \text { serious adverse event, ureterolithiasis, } \\
\text { occurred in the low dose group with full } \\
\text { recovery }\end{array}$ \\
\hline & 9 & Knee OA & $\begin{array}{l}\text { Phase II: } 1.0 \times 10^{8} \text { pure ASCs in } \\
3 \mathrm{~mL} \text { of saline was injected }\end{array}$ & $\begin{array}{l}\text { Consistent articular cartilage regeneration } \\
\text { on second look arthroscopy }\end{array}$ \\
\hline $\begin{array}{l}\text { Koh et al. (April 2014) } \\
\text { [68] }\end{array}$ & 37 & Knee OA & Pure ASC & IKDC and Tegner activity scores improved \\
\hline \multirow[t]{2}{*}{$\begin{array}{l}\text { Kim et al. (January } \\
\text { 2015) [48] }\end{array}$} & Group 1: 37 & Knee OA & SVF implantation without a scaffold & $\begin{array}{l}\text { IKDC and Tegner scores equally } \\
\text { improved, but ICRS score was } \\
\text { significantly better in group } 2 \text { patients. }\end{array}$ \\
\hline & Group 2: 17 & Knee OA & SVF loaded in fibrin glue & \\
\hline $\begin{array}{l}\text { Kim et al. (June 2015) } \\
\text { [69] }\end{array}$ & 49 & Knee OA & SVF plus fibrin glue scaffold & IKDC and Tegner scores improved \\
\hline
\end{tabular}

$O A$ osteoarthritis, $S V F$ stromal vascular fraction, $P R P$ platelet rich plasma, $H A$ hyaluronic acid, $M R I$ magnetic resonance imaging, $I K D C$ International Knee Documentation Committee, ASCs adipose-derived stem cells, ICRS International Cartilage Repair Society 
arthroscopic debridement and injected infrapatellar fat pad SVF in 25 knees. Of the 25 patients, the authors recorded only one reaction, in which the patient experienced marked pain with swelling which resolved spontaneously after 2 weeks. No other major adverse events occurred and many of the patients had improved pain. Consistent improvement in pain scores were noted in a retrospective evaluation of 37 ASC injections in OA knees performed by the same authors a year later [24]. However, the authors did note that cartilage repair was not as optimal as they had expected in larger lesions on second look arthroscopy.

In 2013, Pak reported the almost complete restoration of chondromalacia patella lesions in two patients following SVF injection [71]. The 43-year-old female and 52-year-old male had symptomatic improvement and significant regeneration of tissue on MRI in their lesions 3 months after treatment. In the same report, the author describes almost complete resolution of osteoarthritic pain in a 63-year-old female after SVF injection, subsequent to failed previous injections of platelet rich plasma, hyaluronic acid, and steroids.

The next year, researchers conducting a phases I and II proof of concept report aimed at studying varying doses of ASCs for their injection in OA found that $1 \times 10^{8}$ cells in $3 \mathrm{~mL}$ normal saline was both safe and more efficacious in repairing cartilage than either $1 \times 10^{7}$ or $5 \times 10^{7}$ cells [72]. In phase II of the same study, all nine patients treated with the high dose injections had significant improvements in function and pain. It is noteworthy that this is one of the two only studies using isolated ASCs from the SVF in their treatment groups. As previously described, the separation of ASCs from other cell lines within the SVF requires overnight culturing. Therefore, the clinical studies evaluating the effects of pure ASC are scarce $[68,72]$.

In the most recent comparative study, Kim et al. have published results of ASC therapy for osteoarthritis delivered with a biological scaffold [48]. In this study, the authors divided 54 patients (56 knees) into two groups: 37 (39 knees) treated with ASCs and 17 treated with ASCs loaded in fibrin glue as a scaffold. Similar and significant improvement in pain and function was seen in both groups; however, $58 \%$ of lesions in scaffold-treated patients had achieved a normal or near normal cartilage state while only $23 \%$ of lesions in the ASC group alone had achieved normal or near normal international cartilage repair scores on 12-month follow-up. The results of this study reinforce the efficacy of ASC therapy and report the advantages of delivering ASCs via a scaffold.

\section{Future and Challenges}

Despite the tremendous advances in regenerative medicine that stem cell research has provided, the clinical benefits of using ASCs in cartilage repair is an ongoing investigation and merits more than a handful of case reports and three small comparative studies (see Table 1). This is an exciting time that requires close collaboration between the researcher and orthopedic surgeon. Opportunities for investigation are abundant, and there are significant questions that need to be answered.

The underlying mechanisms that determine the therapeutic influence of ASCs need to be elucidated with a specific focus on the trophic versus constructive effects: i.e., do the cells release cytokines/growth factors to stimulate cartilage regeneration or do they build the cartilage themselves? In vitro and animal studies may clarify these effects and can inform researchers on the next steps to be taken with ASC therapy. If the effects are indeed due to a cytokine release profile rather than the actual regeneration of cartilage from the stem cells, the isolation and production of the implicated factors can save the patient from a safe yet costly liposuction procedure. However, if the implanted cells regenerate the cartilage themselves, then the best method for integration of these cells into native tissue is of significant importance.

Regardless, the benefits of using ASCs in cartilage defects exist despite an unknown mechanism. Therefore, the most efficient, safest method for harvesting and purifying ASCs should be sought. Furthermore, while the use of the SVF and development of commercial SVF isolation devices can allow for intraoperative clinical use of ASCs within minutes after a liposuction procedure, it is not clear at this time whether there is a difference in outcomes after using SVF or purified ASCs. An in vivo trial comparing outcomes in subjects treated with ASCs and SVF would be of significant interest.

In addition to isolation techniques, the optimal dose and delivery route of ASCs needs to be refined, and this treatment must be compared with traditional methods in treating cartilage disorders. Because there is evidence that suggests better cartilage regeneration with the use of scaffolds, a systematic inquiry into the comparisons of various scaffolds in their ability to promote cartilage repair with ASCs should be conducted. Exhaustive trials using ASCs delivery systems that vary scaffold material nanostructure, topography, porosity, adhesiveness, elasticity, strength, and degradation rates must be carried out in order to isolate the scaffolds that provide the best outcomes. Scaffolds must be created that support desirable stem cell differentiation and promote the 3-D regeneration of healthy and functional weight-bearing tissue. Furthermore, these should also be compared with current gold standard treatments. Ultimately, large scale studies evaluating the long-term risks and benefits of using ASCs in treating various cartilage disorders need to be conducted.

\section{Conclusion}

Adipose-derived stem cells have gained significant interest in the fields of regenerative medicine and engineering. The 
results of the clinical studies so far, although limited, suggest that ASCs are safe and useful in the treatment of a wide range of chondral lesions. The use of ASCs offers the advantages of avoiding the multiple surgeries associated with autologous chondrocyte implantation and the morbidity associated with stem cell retrieval from the bone marrow. Furthermore, in vitro and animal studies show regenerated hyaline cartilage upon histological examinations of cartilage defects treated with ASCs. The clinically relevant immuno-modulating effects of ASCs may further their regenerative abilities, and perhaps the most exciting is that the use of ASCs may be beneficial in the treatment of osteoarthritis. In this review, we have attempted to outline the state of affairs of the use of ASCs for cartilage regeneration, and we have provided specific points that need to be addressed in the future. Like many others, we remain cautious yet optimistic about the future of this treatment modality.

Acknowledgments This work was supported by the NIH Director's Pioneer Award 2014, 1DP1AR068147-01.

\section{References}

1. Allen KD, Golightly YM. State of the evidence. Curr Opin Rheumatol. 2015;27(3):276-83.

2. Hunter W. Of the structure and disease of articulating cartilages. Clin Orthop. 1995;317:3-6.

3. Campbell CJ. The healing of cartilage defects. Clin Orthop. 1969;64:45-63.

4. Depalma AF, McKeever CD, Subin DK. Process of repair of articular cartilage demonstrated by histology and autoradiography with tritiated thymidine. Clin Orthop. 1966;48:229-42.

5. Garretson 3rd RB, Katolik LI, Verma N, Beck PR, Bach BR, Cole BJ. Contact pressure at osteochondral donor sites in the patellofemoral joint. Am J Sports Med. 2004;32(4):967-74.

6. Bugbee WD, Convery FR. Osteochondral allograft transplantation. Clin Sports Med. 1999;18(1):67-75.

7. Giannini S, Buda R, Ruffilli A, et al. Failures in bipolar fresh osteochondral allograft for the treatment of end-stage knee osteoarthritis. Knee Surg Sports Traumatol Arthrosc. 2015;23(7):2081-9.

8. Sansone V, de Girolamo L, Pascale W, Melato M, Pascale V. Longterm results of abrasion arthroplasty for full-thickness cartilage lesions of the medial femoral condyle. Arthroscopy: J Arthrosc Relat Surg. 2015;31(3):396-403.

9. O'Driscoll SW. The healing and regeneration of articular cartilage. J Bone Joint Surg Am. 1998;80(12):1795-812.

10. Rae P, Noble J. Arthroscopic drilling of osteochondral lesions of the knee. J Bone Joint Surg (Br). 1989;71(3):534.

11. Eldracher M, Orth P, Cucchiarini M, Pape D, Madry H. Small subchondral drill holes improve marrow stimulation of articular cartilage defects. Am J Sports Med. 2014;42(11):2741-50.

12. Johnson LL. Arthroscopic abrasion arthroplasty historical and pathologic perspective: Present status. Arthroscopy: J Arthrosc Relat Surg. 1986;2(1):54-69.

13. Moseley JB, O'Malley K, Petersen NJ, et al. A controlled trial of arthroscopic surgery for osteoarthritis of the knee. N Engl J Med. 2002;347(2):81-8.
14. Siparsky P, Ryzewicz M, Peterson B, Bartz R. Arthroscopic treatment of osteoarthritis of the knee: are there any evidence-based indications? Clin Orthop Relat Res. 2007;455:107-12.

15. Kaul G, Cucchiarini M, Remberger K, Kohn D, Madry H. Failed cartilage repair for early osteoarthritis defects: a biochemical, histological and immunohistochemical analysis of the repair tissue after treatment with marrow-stimulation techniques. Knee Surg Sports Traumatol Arthrosc. 2012;20(11):2315-24.

16. Redman S, Oldfield S, Archer C. Current strategies for articular cartilage repair. Eur Cell Mater. 2005;9(23-32):23-32.

17. Harris JD, Siston RA, Pan X, Flanigan DC. Autologous chondrocyte implantation: a systematic review. J Bone Joint Surg Am. 2010;92(12):2220-33.

18. Minas T, Von Keudell A, Bryant T, Gomoll AH. The John Insall award: a minimum 10-year outcome study of autologous chondrocyte implantation. Clin Orthop Relat Res. 2014;472(1):41-51.

19. Matricali GA, Dereymaeker G, Luyten FP. Donor site morbidity after articular cartilage repair procedures: a review. Acta Orthop Belg. 2010;76(5):669.

20. Wakitani S, Imoto K, Yamamoto T, Saito M, Murata N, Yoneda M. Human autologous culture expanded bone marrow mesenchymal cell transplantation for repair of cartilage defects in osteoarthritic knees. Osteoarthr Cartil. 2002;10(3):199-206.

21. Davatchi F, Abdollahi BS, Mohyeddin M, Shahram F, Nikbin B. Mesenchymal stem cell therapy for knee osteoarthritis. Preliminary report of four patients. Int J Rheum Dis. 2011;14(2):211-5.

22. Wakitani S, Mitsuoka T, Nakamura N, Toritsuka Y, Nakamura Y, Horibe $\mathrm{S}$. Autologous bone marrow stromal cell transplantation for repair of full-thickness articular cartilage defects in human patellae: two case reports. Cell Transplant. 2004;13(5):595-600.

23. Koh Y, Choi Y. Infrapatellar fat pad-derived mesenchymal stem cell therapy for knee osteoarthritis. Knee. 2012;19(6):902-7.

24. Koh Y, Choi Y, Kwon S, Kim Y, Yeo J. Clinical results and secondlook arthroscopic findings after treatment with adipose-derived stem cells for knee osteoarthritis. Knee Surg Sports Traumatol Arthrosc. 2013;23(5):1308-16.

25. Koh Y, Jo S, Kwon O, et al. Mesenchymal stem cell injections improve symptoms of knee osteoarthritis. Arthroscopy: J Arthrosc Relat Surg. 2013;29(4):748-55.

26. Friedenstein AJ, Gorskaja JF, Kulagina NN. Fibroblast precursors in normal and irradiated mouse hematopoietic organs. Exp Hematol. 1976;4(5):267-74.

27. Dominici M, Le Blanc K, Mueller I, et al. Minimal criteria for defining multipotent mesenchymal stromal cells. the international society for cellular therapy position statement. Cytotherapy. 2006;8(4):315-7.

28. Pittenger MF, Mackay AM, Beck SC, et al. Multilineage potential of adult human mesenchymal stem cells. Science. 1999;284(5411): $143-7$.

29. Wu L, Leijten JC, Georgi N, Post JN, van Blitterswijk CA, Karperien M. Trophic effects of mesenchymal stem cells increase chondrocyte proliferation and matrix formation. Tissue Eng A. 2011;17(9-10):1425-36.

30. Soleymaninejadian E, Pramanik K, Samadian E. Immunomodulatory properties of mesenchymal stem cells: cytokines and factors. Am J Reprod Immunol. 2012;67(1):1-8.

31. Singer NG, Caplan AI. Mesenchymal stem cells: mechanisms of inflammation. Ann Rev Pathol: Mech Dis. 2011;6:457-78.

32. Kern S, Eichler H, Stoeve J, Klüter H, Bieback K. Comparative analysis of mesenchymal stem cells from bone marrow, umbilical cord blood, or adipose tissue. Stem Cells. 2006;24(5):1294-301.

33. Hernigou P, Desroches A, Queinnec S, et al. Morbidity of graft harvesting versus bone marrow aspiration in cell regenerative therapy. Int Orthop. 2014;38(9):1855-60.

34. Rickard DJ, Kassem M, Hefferan TE, Sarkar G, Spelsberg TC, Riggs BL. Isolation and characterization of osteoblast precursor 
cells from human bone marrow. J Bone Miner Res. 1996;11(3): 312-24.

35. Li J, Wong WH, Chan S, et al. Factors affecting mesenchymal stromal cells yield from bone marrow aspiration. Chin J Cancer Res. 2011;23(1):43-8.

36. Fennema EM, Renard AJ, Leusink A, van Blitterswijk CA, de Boer $J$. The effect of bone marrow aspiration strategy on the yield and quality of human mesenchymal stem cells. Acta Orthop. 2009;80(5):618-21.

37. da Silva ML, Sand TT, Harman RJ, Lennon DP, Caplan AI. MSC frequency correlates with blood vessel density in equine adipose tissue. Tissue Eng A. 2008;15(2):221-9.

38. Horwitz E, Le Blanc K, Dominici M, et al. Clarification of the nomenclature for MSC: The International Society for Cellular Therapy position statement. Cytotherapy. 2005;7(5):393-5.

39. Zuk PA, Zhu M, Mizuno H, et al. Multilineage cells from human adipose tissue: implications for cell-based therapies. Tissue Eng. 2001;7(2):211-28

40. Tonnard P, Verpaele A, Peeters G, Hamdi M, Cornelissen M, Declercq H. Nanofat grafting: basic research and clinical applications. Plast Reconstr Surg. 2013;132(4):1017-26.

41. Huang JI, Zuk PA, Jones NF, et al. Chondrogenic potential of multipotential cells from human adipose tissue. Plast Reconstr Surg. 2004;113(2):585-94.

42. English A, Jones EA, Corscadden D, et al. A comparative assessment of cartilage and joint fat pad as a potential source of cells for autologous therapy development in knee osteoarthritis. Rheumatology (Oxford). 2007;46(11):1676-83.

43. Zuk P. Adipose-derived stem cells in tissue regeneration: a review. ISRN Stem Cells. 2013;2013

44. Lin C, Lin G, Lue TF. Allogeneic and xenogeneic transplantation of adipose-derived stem cells in immunocompetent recipients without immunosuppressants. Stem Cells Dev. 2012;21(15):2770-8.

45. González MA, Gonzalez-Rey E, Rico L, Büscher D, Delgado M. Adipose-derived mesenchymal stem cells alleviate experimental colitis by inhibiting inflammatory and autoimmune responses. Gastroenterology. 2009;136(3):978-89.

46. Vanikar AV, Trivedi HL. Stem cell transplantation in living donor renal transplantation for minimization of immunosuppression. Transplantation. 2012;94(8):845-50.

47. Gonzalez-Rey E, Gonzalez MA, Varela N, et al. Human adiposederived mesenchymal stem cells reduce inflammatory and $\mathrm{T}$ cell responses and induce regulatory $\mathrm{T}$ cells in vitro in rheumatoid arthritis. Ann Rheum Dis. 2010;69(1):241-8.

48. Kim YS, Choi YJ, Suh DS, et al. Mesenchymal stem cell implantation in osteoarthritic knees: is fibrin glue effective as a scaffold? Am J Sports Med. 2015;43(1):176-85.

49. Housman TS, Lawrence N, Mellen BG, et al. The safety of liposuction: results of a national survey. Dermatol Surg. 2002;28(11): 971-8.

50. American Society for Aesthetic Plastic Surgery: http://www. surgery.org/media/news-releases/the-american-society-foraesthetic-plastic-surgery-reports-americans-spent-more-than-12billion-in-2014-pro. 2014, Accessed 6/2015

51. Venkataram J. Tumescent liposuction: a review. J Cutan Aesthet Surg. 2008;1(2):49-57.

52. Markarian CF, Frey GZ, Silveira MD, et al. Isolation of adiposederived stem cells: a comparison among different methods. Biotechnol Lett. 2014;36(4):693-702.

53. Raposio E, Caruana G, Bonomini S, Libondi G. A novel and effective strategy for the isolation of adipose-derived stem cells: minimally manipulated adipose-derived stem cells for more rapid and safe stem cell therapy. Plast Reconstr Surg. 2014;133(6):1406-9.
54. Aronowitz JA, Ellenhorn JD. Adipose stromal vascular fraction isolation: a head-to-head comparison of four commercial cell separation systems. Plast Reconstr Surg. 2013;132(6):932e-9e.

55. Kim YS, Park EH, Kim YC, Koh YG. Clinical outcomes of mesenchymal stem cell injection with arthroscopic treatment in older patients with osteochondral lesions of the talus. Am J Sports Med. 2013;41(5):1090-9.

56. Ha CW, Park YB. Mesenchymal stem cell injection for osteochondral lesions of the talus: letter to the editor. Am J Sports Med. 2014;42(2):NP19-20.

57. Ha CW, Park YB. Mesenchymal stem cell injection for osteochondral lesions of the talus: letter to the editor. Am J Sports Med. 2014;42(6):NP34-5.

58. ter Huurne M, Schelbergen R, Blattes R, et al. Anti-inflammatory and chondroprotective effects of intraarticular injection of adiposederived stem cells in experimental osteoarthritis. Arthritis Rheum. 2012;64(11):3604-13.

59. Fatemehsadat Toghraie D, Chenari N, Ghaderi A. Scaffold-free adipose-derived stem cells (ASCs) improve experimentally induced osteoarthritis in rabbits. Arch Iran Med. 2012;15(8):495.

60. Vilar JM, Batista M, Morales M, et al. Assessment of the effect of intraarticular injection of autologous adipose-derived mesenchymal stem cells in osteoarthritic dogs using a double blinded force platform analysis. BMC Vet Res. 2014;10(1):143.

61. Hutmacher DW. Scaffolds in tissue engineering bone and cartilage Biomaterials. 2000;21(24):2529-43.

62. Cui L, Wu Y, Cen L, et al. Repair of articular cartilage defect in nonweight bearing areas using adipose derived stem cells loaded polyglycolic acid mesh. Biomaterials. 2009;30(14):2683-93.

63. Masuoka K, Asazuma T, Hattori $\mathrm{H}$, et al. Tissue engineering of articular cartilage with autologous cultured adipose tissue-derived stromal cells using atelocollagen honeycomb-shaped scaffold with a membrane sealing in rabbits. J Biomed Mater Res B Appl Biomater. 2006; 79(1):25-34

64. Zhang K, Zhang Y, Yan S, et al. Repair of an articular cartilage defect using adipose-derived stem cells loaded on a polyelectrolyte complex scaffold based on poly (1-glutamic acid) and chitosan. Acta Biomater. 2013;9(7):7276-88.

65. Laurencin CT, Khan Y. Regenerative engineering. Boca Raton, FL: CRC Press; 2013.

66. Pak J, Chang JJ, Lee JH, Lee SH. Safety reporting on implantation of autologous adipose tissue-derived stem cells with platelet-rich plasma into human articular joints. BMC Musculoskelet Disord. 2013; 14:337-2474-14-337.

67. Pak J, Lee JH, Lee SH. Regenerative repair of damaged meniscus with autologous adipose tissue-derived stem cells. Biomed Res Int. 2014;2014:436029.

68. Koh YG, Choi YJ, Kwon OR, Kim YS. Second-look arthroscopic evaluation of cartilage lesions after mesenchymal stem cell implantation in osteoarthritic knees. Am J Sports Med. 2014;42(7):1628-37.

69. Kim YS, Choi YJ, Koh YG. Mesenchymal stem cell implantation in knee osteoarthritis an assessment of the factors influencing clinical outcomes. Am J Sports Med. 2015:0363546515588317.

70. Pak J. Regeneration of human bones in hip osteonecrosis and human cartilage in knee osteoarthritis with autologous adipose-tissuederived stem cells: a case series. J Med Case Rep. 2011;5:2961947-5-296

71. Pak J, Lee JH, Lee SH. A novel biological approach to treat chondromalacia patellae. PLoS ONE. 2013;8(5), e64569.

72. Jo CH, Lee YG, Shin WH, et al. Intra-Articular injection of mesenchymal stem cells for the treatment of osteoarthritis of the knee: a proof-of-concept clinical trial. Stem Cells. 2014;32(5):1254-66.

73. Food and Drug Administration. Cell Therapy. Korean Food and Drug Administration Rules and Regulations. 2009; 2:12. 